\title{
PENGARUH REWARD TERHADAP KNOWLEDGE SHARING PERANGKAT DESA BERDAMPAK PENINGKATAN PARTISIPASI MASYARAKAT
}

\author{
Faisal Amri ${ }^{1}$, Ida Yusnita ${ }^{2}$, Ayu Esteka Sari*3 \\ 1,2,3 Jurusan Manajemen, STIE Sakti Alam Kerinci, Sungai Penuh, Jambi, Indonesia \\ *e-mail: ayuesteka82@gmail.com
}

\begin{abstract}
ABSTRAK
Penelitian ini memiliki tujuan mendapatkan hasil dari pengaruh reward terhadap knowledge sharing perangkat desa berdampak terhadap peningkatan partisipasi masyarakat. Reward pada penelitian ini terbagi atas Extrinsic Rewards dan Intrinsic Rewards. Penelitian ini dilaksanakan di Kabupaten Kerinci dengan Perangkat desa sebagai subjek penelitian. Penelitian ini dilaksanakan pada Bulan Juni 2020 - September 2020. Perangkat Desa di Kabupaten Kerinci merupakan populasi dalam penelitian ini dengan menggunakan metode penarikan sampel adalah Cluster Sampling dengan mengelompokkan sampel didasari wilayah dengan jumlah sampel adalah 108 responden. Sumber data didapatkan dari wawancara (interview) serta daftar pertanyaan (questionnaire). Pada penelitian ini menggunakan analisis data Structural Equation Models (SEM) serta menggunakan AMOS sebagai alat analisis. Hasil penelitian didapatkan koefisien determinasi besar pengaruh knowledge sharing yang dapat dijelaskan oleh variabel extrinsic rewards dan intrinsic rewards sebesar 17\%. Sedangkan koefisien determinasi persamaan Partisipasi Masyarakat sebesar 20,2\%. Hasil dari penelitian didapatkan dari pengujian hipotesis bahwa extrinsic rewards dan intrinsic rewards memiliki pengaruh yang positif dan signifikan terhadap knowledge sharing, knowledge sharing dan intrinsic rewards berpengaruh positif dan signifikan terhadap partisipasi masyarakat sedangkan extrinsic rewards berpengaruh tidak signifikan terhadap partisipasi masyarakat. Knowledge Sharing dalam penelitian ini bukan merupakan variabel intervening karena pengaruh langsung extrinsic rewards terhadap partisipasi masyarakat lebih besar dari pada pengaruh tidak langsung melalui knowledge sharing dan pengaruh langsung intrinsic rewards terhadap partisipasi masyarakat juga lebih besar dari pengaruh tidak langsung terhadap partisipasi masyarakat melalui knowledge sharing. Hasil dari penelitian ini memberikan bukti empiris sebagai panduan bagi pemerintahan dan perangkat desa untuk menetapkan strategi yang tepat dalam knowledge sharing dan meningkatkan partisipasi masyarakat termasuk dampak terhadap pembangunan daerah.
\end{abstract}

Kata Kunci: Extrinsic Rewards, Intrinsic Rewards, Knowledge Sharing, Partisipasi Masyarakat

\begin{abstract}
This study has the aim of obtaining the results of the effect of reward on knowledge sharing of village officials, having an impact on increasing community participation. Rewards in this study are divided into Extrinsic Rewards and Intrinsic Rewards. The focus of this research is in Kerinci Regency with village officials as research subjects. This research was conducted in June 2020 and completed in September 2020. Village officials in Kerinci Regency are the population in this study using the sampling method, namely Cluster Sampling, by grouping samples based on regions with a total sample size of 108 respondents. Sources of data obtained from interviews (interview) and a list of questions (questionnaire). This study uses data analysis of Structural Equation Models (SEM) and uses AMOS as an analysis tool. The results showed the coefficient of determination of the influence of
\end{abstract}


knowledge sharing which can be explained by extrinsic rewards and intrinsic rewards variables by 17\%. Meanwhile, the coefficient of determination of the Community Participation equation is 20.2\%. The results of the study were obtained from testing the hypothesis that extrinsic rewards and intrinsic rewards have a positive and significant effect on knowledge sharing, knowledge sharing and intrinsic rewards have a positive and significant effect on community participation, while extrinsic rewards have no significant effect on community participation. Knowledge Sharing in this study is not an intervening variable because the direct effect of extrinsic rewards on community participation is greater than the indirect effect through knowledge sharing and the direct effect of intrinsic rewards on community participation is also greater than the indirect effect on community participation through knowledge sharing.

Keywords: Extrinsic Rewards, Intrinsic Rewards, Knowledge Sharing, Community Participation

\section{PENDAHULUAN}

Berdasarkan Pancasila dan UUD 1945 tujuan dari Pemerintah dan seluruh rakyat Indonesia adalah untuk mencapai cita-cita dan tujuan nasional yaitu mencapai masyarakat adil, makmur dan sejahtera. Dengan jumlah 83.931 desa yang tersebar di seluruh Indonesia diharapkan kesejahteraan rakyat bisa menjangkau sampai kepada pelosok desa. Masing-masing desa memiliki wewenang untuk membuat perencanaan desa yang disebut Rencana Pembangunan Jangka Menengah Desa (RPJM). Perencanaan dari pembangunan pedesaan didukung oleh dana yang didapatkan dari pemerintah seperti dengan adanya Dana Desa (DD). Dana desa yang diberikan kepada masing-masing desa bertujuan untuk mengoptimalkan potensi yang dimiliki oleh masing-masing desa, serta lebih menggali lebih dalam potensi yang dimiliki tersebut. Pemerintah mengharapkan dengan pemanfaatan dari Dana Desa yang tepat dengan sasaran dan sumber daya yang dimiliki desa bisa meningkatkan partisipasi masyarakat untuk bersama dan saling bekerja sama untuk membangun Desa.

Salah satu faktor yang menunjang terbentuknya kesesuaian antara perencanaan pembangunan desa dengan tercapainya keseluruhan kegiatan dan proses pembangunan desa adalah partisipasi masyarakat. Partisipasi masyarakat merupakan dasar utama untuk pelaksanaan pembangunan, karena masyarakat lah yang merupakan penunjang dan sebagai pelaksana kegiatan. Hal yang paling utama menjadikan alasan di atas adalah masyarakat desa yang paling mengetahui dari sumber daya yang dimiliki, potensi yang dimiliki serta apa yang diinginkan dan diperlukan oleh masyarakat desa. Masyarakat desa lebih mengetahui pembangunan yang paling dibutuhkan dan diperlukan. Sehingga hasil yang diciptakan tepat dan sesuai dengan sasaran. 
Masyarakat desa yang memiliki keterbatasan sumber daya, khususnya sumber daya manusia membutuhkan bantuan dari orang-orang yang lebih berpengalaman dan mengetahui dari segi keilmuan dan skill yang dimiliki. Salah satu elemen yang bisa mencapai hal tersebut adalah dengan adanya perangkat desa yang berpengalaman dan memiliki skill manajemen yang baik. Perangkat desa memiliki tanggung jawab dan wewenang yang telah tertuang di dalam tugas pokok dan fungsi mereka masing-masing. Dengan adanya kesesuaian dan kerja sama yang baik antara perangkat desa dengan masyarakat desa maka semua tujuan pembangunan desa akan tercapai [1].

Dari knowledge sharing perangkat desa maka diharapkan partisipasi masyarakat akan meningkat. Knowledge sharing memiliki efek beragam pada organisasi salah satunya kreativitas dari perangkat desa yang memberikan dampak meningkatkan kinerja perangkat desa [2]. Sumber daya pengetahuan telah menghadapi usaha serius. Banyak peneliti dan cendekiawan percaya bahwa sumber pengetahuan harus diperhatikan dan dikelola dengan mengubah tacit knowledge menjadi explicit knowledge [3]. Knowledge sharing adalah sebuah proses dimana explicit knowledge atau tacit dikomunikasikan kepada individu lainnya [4], Knowledge sharing tercipta dan terjadi jika ada kemauan dari orang lain untuk saling berbagi ilmu, mampu dan memiliki keinginan untuk membantu orang lain, serta belajar dari orang lain [5]. Knowledge sharing merupakan interaksi antara individu dan kelompok; di dalam, di antara, dan di seluruh kelompok; dan dari kelompok ke organisasi [6] Sehingga untuk mengelola desa dibutuhkan knowledge sharing antara perangkat desa dan keseluruhan elemen di Desa untuk menunjang terjadinya pembangunan desa yang adil dan merata. Adapun indikator dari knowledge sharing yang terdiri dari teknologi, organisasi, individu, penyampaian layanan, kinerja organisasi dan kualitas knowledge sharing [7].

Setiap organisasi membutuhkan sistem penghargaan (reward) atau imbalan yang diberikan kepada karyawan, tujuan dari pemberian penghargaan ini adalah menjadikan sebagai motivasi kepada karyawan untuk bisa bekerja lebih bersemangat dan tentu saja bertujuan mencapai kinerja dan produktivitas. Imbalan didefinisikan mencakup semua jenis tunjangan, mulai dari pembayaran tunai hingga kondisi kerja [8]. Ada dua jenis reward yaitu : extrinsic rewards dan intrinsic rewards [8]. Extrinsic rewards adalah karakteristik nyata atau eksternal dari pekerjaan tersebut, seperti kompensasi, promosi, tunjangan tambahan, fleksibilitas tenaga kerja, dan keamanan kerja [9] sedangkan intrinsic rewards adalah kebutuhan manusia untuk menjadi kompeten dan menentukan nasib sendiri dalam hubungannya dengan lingkungan, untuk melibatkan kepentingan seseorang dan melatih 
kapasitas seseorang [9]. Indikator dari extrinsic rewards biasanya terkait langsung dengan masalah gaji atau kompensasi [8], yaitu : bagi hasil (profit sharing), pembagian keuntungan (gain sharing), jaminan kerja (employment security), upah lembur (overtime pay), sistem kinerja berbasis individu (individual based performance system) dan sistem kinerja berbasis kuantitas (quantity based performance system) untuk indikator dari intrinsic rewards yang terdiri dari empat indikator adalah : rasa bermakna (sense of meaning fullness), memiliki rasa untuk memilih (sense of choice), rasa untuk berkompetensi (sense of competence) dan rasa untuk bisa lebih maju (sense of progress) [10].

Untuk pemerintah khususnya level desa, manfaat mempertimbangkan kontribusi masyarakat sipil adalah penting dan termasuk penyediaan pengetahuan [11]. Partisipasi dalam kehidupan sipil umumnya mengacu pada berbagai cara individu berinteraksi dengan komunitas yang lebih luas dan konteks sosial di mana dia tinggal [12]. Partisipasi masyarakat dapat meningkatkan pengambilan keputusan lingkungan, dengan indikator dari partisipasi masyarakat adalah : partisipasi, fasilitas, konteks, karakteristik peserta, dan keanekaragaman peserta [13].

Dengan adanya saling berbagi pengetahuan (knowledge sharing) perangkat desa, baik itu dengan sesama perangkat desa dengan masyarakat desa maka pembangunan di tahap dan level desa akan tercapai, semua perencanaan desa akan tercapai sesuai dengan Musrenbang Desa yang telah direncanakan di awal tahun dan tentunya partisipasi masyarakat desa terjadi peningkatan dan kemajuan.

Tujuan dari penelitian ini adalah untuk mengetahui pengaruh reward terhadap knowledge sharing perangkat desa dan dampaknya terhadap partisipasi masyarakat desa di Kabupaten Kerinci dalam pembangunan pedesaan. Urgensi dari penelitian adalah peran knowledge sharing perangkat desa untuk mengaplikasikan tugas dan tanggung jawab yang dimiliki untuk mengatur dan me-manage desa untuk peningkatan partisipasi keseluruhan masyarakat yang berada di desa sehingga diharapkan bisa meningkatkan kesejahteraan dan pendapatan masyarakat.

\section{METODE PENELITIAN}

Penelitian ini dilaksanakan pada Bulan Juni 2020 dan selesai pada Bulan September 2020. Desain penelitian ini membuat kerangka dari pengaruh reward terhadap knowledge sharing perangkat desa dan dampaknya terhadap partisipasi masyarakat di Kabupaten Kerinci. Dalam penelitian ini yang merupakan populasi adalah perangkat desa di Kabupaten Kerinci, dengan 
sampel sebanyak 108 responden dengan teknik penarikan sampel menggunakan cluster sampling dengan mengelompokkan sampel yang terdiri dari wilayah [14]. Sumber data dalam penelitian ini berasal dari perangkat desa yang dijadikan sampel. Data yang diperoleh dengan cara mewawancarai perangkat desa serta memberikan kuesioner atau daftar pertanyaan yang diisi oleh perangkat desa. Kuesioner yang diberikan bersifat rahasia tidak akan disebarluaskan dan hanya digunakan untuk keperluan penelitian.

Sesuai penjelasan di atas, maka desain penelitian untuk mengetahui pengaruh yang menyatakan korelasi antar variabel dari reward terhadap knowledge sharing perangkat desa dan dampaknya terhadap partisipasi masyarakat di Kabupaten Kerinci, sebagai berikut:

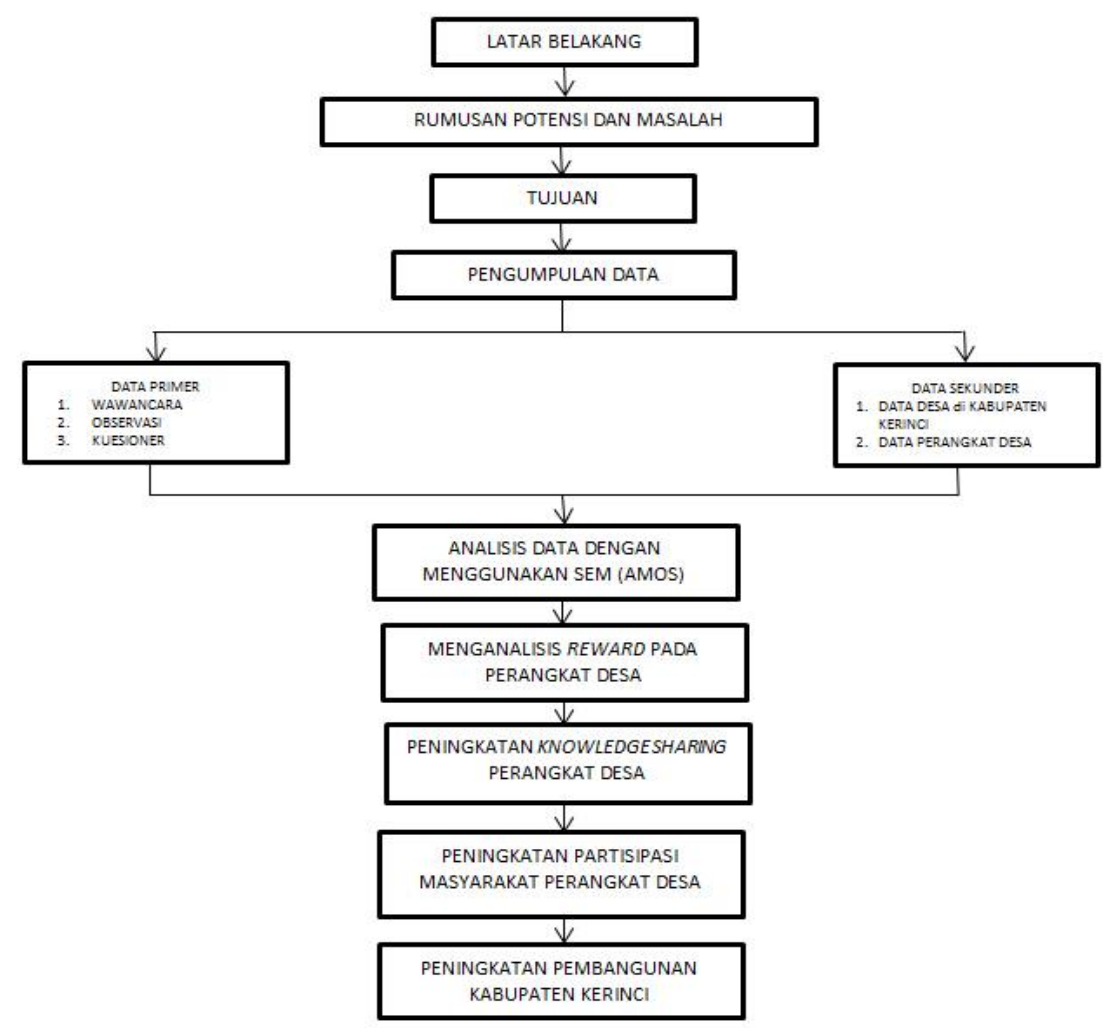

\section{Gambar 1. Desain Penelitian}

Model persamaan struktural atau Structural Equation Model (SEM) merupakan model yang digunakan pada penelitian ini. Structural Equation Model (SEM) merupakan penggabungan analisis jalur (Path analysis) serta analisis faktor yang menjadi satu dalam sebuah metode statistik yang bersamaan [15]. Alat analisis yang digunakan adalah dengan menggunakan AMOS (Analysis of Moment Structure). Model AMOS (Analysis of Moment Structure) dikembangkan oleh J. Arbucle merupakan program yang digunakan untuk mengolah model dalam sebuah penelitian teknik manajemen serta ilmu-ilmu sosial [15]. 
Untuk menilai kelayakan sebuah model dengan ukuran yang digunakan (Goodness-of-Fit) adalah: (1) absolute fit indices, (2) incremental fit indices dan (3) Parsimonious fit indices. Untuk pengujian secara simultan (struktural) pada uji hipotesis dalam perhitungan Structural Equation Model (SEM) perhitungan t hitung atau t test menggunakan CR (Critical Ratio) dengan ketetapan adalah $\mathrm{H} 0$ ditolak jika $\mathrm{CR} \geq 1,96$ pada level $\alpha 5 \%$ [15].

\section{HASIL DAN PEMBAHASAN}

\subsection{Hasil Penelitian}

Pada gambar 2 di bawah ini, hasil dari Full Model-Structural Equation Model (SEM, dengan hasil pengujian adalah sebagai berikut :

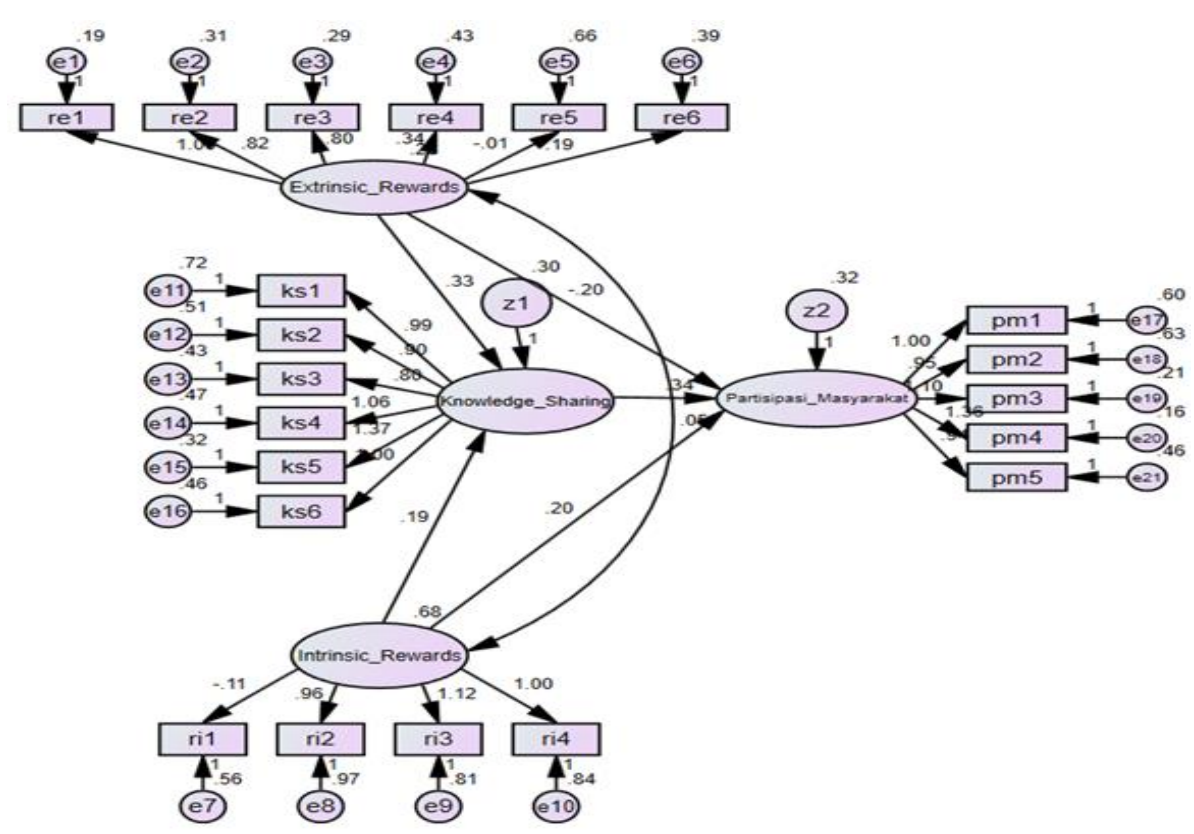

Gambar 2. Result Full Model-Structural Equation Model (SEM)

Hasil dari Pengujian Structural Equation Model (SEM) dengan perhitungan model secara penuh (Full Model) dibandingkan dengan kriteria tingkat kesesuaian (testing fit) adalah:

Tabel 1. Kriteria Testing Fit

\begin{tabular}{|c|c|c|}
\hline No & Testing Fit & Tingkat Kecocokan Yang Bisa Diterima \\
\hline 1 & Absolute Fit Indices & \\
\hline \multirow{6}{*}{2} & DF & Diterima Jika Positif \\
\hline & $X 2 / \mathrm{DF}$ & Batas terendah 1,0 , batas tertinggi 2,03 \\
\hline & Incremental Fit Indices & \\
\hline & - GFI & Nilai Berkisar 0-1, mendekati 1 semakin baik \\
\hline & - AGFI & \\
\hline & - TLI & \\
\hline
\end{tabular}




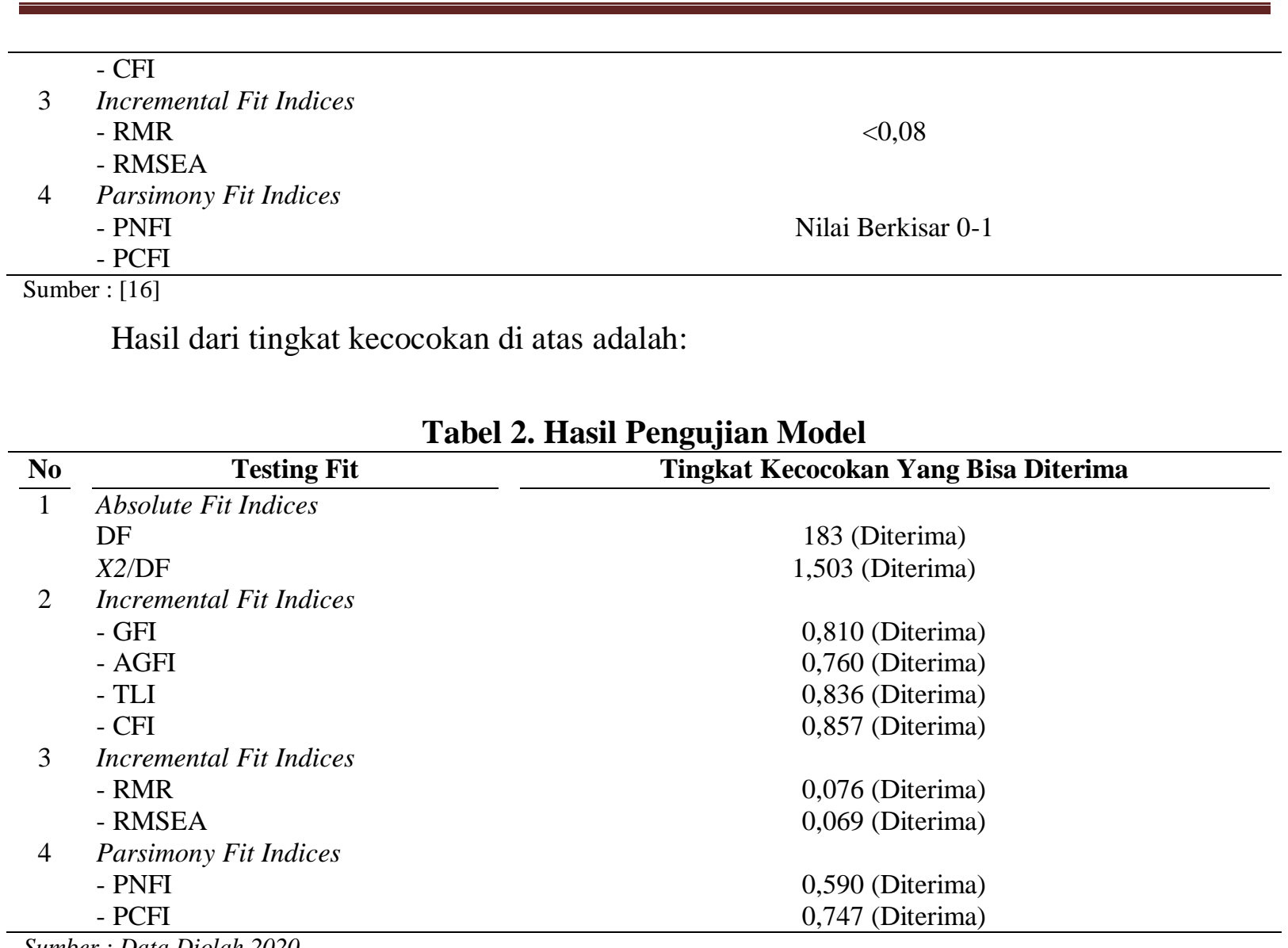

Sumber : Data Diolah 2020

Hasil output menunjukkan hasil dari persamaan regresinya adalah sebagai berikut:

Tabel 3. Model Result Test

\begin{tabular}{lllc}
\hline & & & Estimate \\
\hline Knowledge_Sharing & $<---$ & Extrinsic_Rewards & .294 \\
\hline Knowledge_Sharing & $<---$ & Intrinsic_Rewards & .259 \\
Partisipasi_Masyarakat & $<---$ & Knowledge_Sharing & .321 \\
Partisipasi_Masyarakat & $<---$ & Extrinsic_Rewards & -.166 \\
\hline Partisipasi_Masyarakat & $<---$ & Intrinsic_Rewards & .258 \\
\hline
\end{tabular}

Berikut ini penjelasan dari tabel 3 terkait persamaan regresinya.

$$
\begin{array}{ll}
\text { Knowledge Sharing } & =0,294 \mathrm{ER}+0,259 \mathrm{IR} \\
\text { Partisipasi_Masyarakat } & =0,321 \mathrm{KS}-0,166 \mathrm{ER}+0,258 \mathrm{IR}
\end{array}
$$

Tabel 4. Hasil Koefisien Determinasi (KD)

\begin{tabular}{|l|c|}
\hline & Estimate \\
\hline Knowledge_Sharing & .170 \\
Partisipasi_Masyarakat & .202 \\
\hline Sumber : Data Diolah 2020
\end{tabular}


Untuk persamaan Koefisien Determinasi (KD) knowledge sharing sebesar 0.170 yang berarti variabilitas knowledge sharing yang dapat dijelaskan oleh variabel extrinsic rewards dan intrinsic rewards sebesar $17 \%$. Sedangkan koefisien determinasi persamaan partisipasi masyarakat sebesar 0,202 atau variabel partisipasi masyarakat yang dapat dijelaskan oleh variabilitas extrinsic rewards, intrinsic rewards dan knowledge sharing sebesar 20, $2 \%$.

\section{Hypothesis Test}

Hipotesis yang diuji dengan menggunakan model Structural Equation Model (SEM) pada penelitian ini menggunakan kriteria critical ratio dengan syarat atau kriteria yang ditetapkan adalah nilainya harus lebih besar dari 1,96 atau tingkat signifikansinya harus dibawah 0,05 (5\%). Pengujian hipotesis yang didapatkan pada penelitian ini bisa dilihat pada tabel, berikut:

Tabel 5. Model Test Result

\begin{tabular}{lll|rrrrc}
\hline & & & \multirow{2}{*}{$\begin{array}{c}\text { Critical } \\
\end{array}$} & & & S.E. value & Label \\
Patio & Pare \\
\hline Knowledge_Sharing & $<---$ & Extrinsic_Rewards & .333 & .156 & 2.144 & .032 & par_18 \\
Knowledge_Sharing & $<---$ & Intrinsic_Rewards & .189 & .091 & 2.066 & .039 & par_22 \\
Partisipasi_Masyarakat & $<---$ & Knowledge_Sharing & .336 & .144 & 2.329 & .020 & par_19 \\
Partisipasi_Masyarakat & $<---$ & Extrinsic_Rewards & -.198 & .147 & -1.341 & .180 & par_20 \\
Partisipasi_Masyarakat & $<---$ & Intrinsic_Rewards & .197 & .098 & 2.008 & .045 & par_21 \\
\hline Sumber :Data Diolah 2020 & & & & & & &
\end{tabular}

Penjelasan yang bisa didapatkan dari hasil pengujian hipotesis pada tabel 5, antara lain:

1. Extrinsic Rewards terhadap Knowledge Sharing

Hipotesis 1 diterima dikarenakan hasil dari nilai critical ratio adalah 2,144 hal ini dimaknai hasil critical ratio $\geq 1,96$ serta didapatkan nilai dari probabilitas di bawah atau $\leq 0,05$ yakni sebesar 0,032 . Sehingga dari penelitian didapatkan kesimpulan extrinsic rewards berpengaruh positif serta signifikan terhadap knowledge sharing dapat diterima.

2. Intrinsic Rewards terhadap Knowledge Sharing

Hipotesis 2 diterima dikarenakan hasil dari Nilai critical ratio adalah 2,066 hal ini dimaknai hasil critical ratio $\geq 1,96$ serta didapatkan nilai dari probabilitas adalah $\leq 0,05$ yakni dengan nilai besarnya adalah 0,039. Sehingga dari penelitian didapatkan kesimpulan intrinsic rewards berpengaruh positif serta signifikan terhadap knowledge sharing dapat diterima. 
3. Knowledge Sharing terhadap Partisipasi Masyarakat

Hipotesis 3 diterima dikarenakan hasil dari Nilai critical ratio adalah 2,329 hal ini dimaknai hasil critical ratio $\geq 1,96$ serta didapatkan nilai dari probabilitas adalah $\leq 0,05$ yakni dengan nilai besarnya adalah 0,020. Sehingga dari penelitian didapatkan kesimpulan knowledge sharing berpengaruh positif serta signifikan terhadap partisipasi masyarakat diterima.

4. Extrinsic_Rewards berpengaruh tidak signifikan terhadap Partisipasi Masyarakat Hipotesis 4 ditolak dikarenakan hasil dari Nilai critical ratio adalah - 1,341 hal ini dimaknai hasil critical ratio critical ratio $\geq 1,96$ serta didapatkan nilai dari probabilitas adalah $\leq 0,05$ yakni dengan nilai besarnya adalah 0,180 . Sehingga dari penelitian didapatkan kesimpulan bahwa extrinsic rewards berpengaruh tidak signifikan dengan partisipasi masyarakat ditolak.

5. Intrinsic_Rewards berpengaruh positif dan signifikan terhadap Partisipasi Masyarakat Hipotesis 5 diterima dikarenakan hasil dari Nilai critical ratio adalah 2,008 hal ini dimaknai hasil critical ratio critical ratio $\geq 1,96$ serta didapatkan nilai dari probabilitas adalah $\leq 0,05$ yakni dengan nilai besarnya adalah 0,045. Sehingga dari penelitian didapatkan kesimpulan intrinsic rewards berpengaruh positif serta signifikan terhadap partisipasi masyarakat diterima.

\section{Analisis Pengaruh dari Direct Effect, Indirect Effect dan Total Effect}

Dalam path analysis dengan menggunakan variabel intervening maka dibutuhkan analisis untuk melihat hasil dari penelitian berdasarkan pengaruh direct effect, indirect effect dan total effect. Dari analisis data dan hasil dari penelitian maka didapatkan hasil pada tabel 6, tabel 7 dan tabel 8, berikut:

Tabel 6. Standardized Direct Effects

\begin{tabular}{lcccc}
\hline & Intrinsic_Rewards & Extrinsic_Rewards Knowledge_Sharing Partisipasi_Masyarakat \\
\hline Knowledge_Sharing & .259 & .294 & .000 & .000 \\
Partisipasi_Masyarakat & .258 & -.166 & .321 & .000 \\
\hline Sumber : Data Diolah 2020 & & &
\end{tabular}

Tabel 7. Standardized Indirect Effects

\begin{tabular}{|l|cccc|}
\hline & Intrinsic_Rewards & Extrinsic_Rewards Knowledge_Sharing & Partisipasi_Masyarakat \\
\hline Knowledge_Sharing & .000 & .000 & .000 & .000 \\
Partisipasi_Masyarakat & .083 & .094 & .000 & .000 \\
\hline
\end{tabular}

Sumber : Data Diolah 2020 
Tabel 8. Standardized Total Effects

\begin{tabular}{|l|cccc|}
\hline & Intrinsic_Rewards & Extrinsic_Rewards & Knowledge_Sharing & Partisipasi_Masyarakat \\
\hline Knowledge_Sharing & .259 & .294 & .000 & .000 \\
Partisipasi_Masyarakat & .341 & -.072 & .321 & .000 \\
\hline Sumber:Data Diolah 2020 & & &
\end{tabular}

Sumber : Data Diolah 2020

Berdasarkan tabel 6 sampai dengan 8 dapat dibuat diagram gabungan pengaruh langsung dan pengaruh tidak langsung. Diagram dari penjelasan tabel 6, tabel 7 dan tabel 8 adalah:

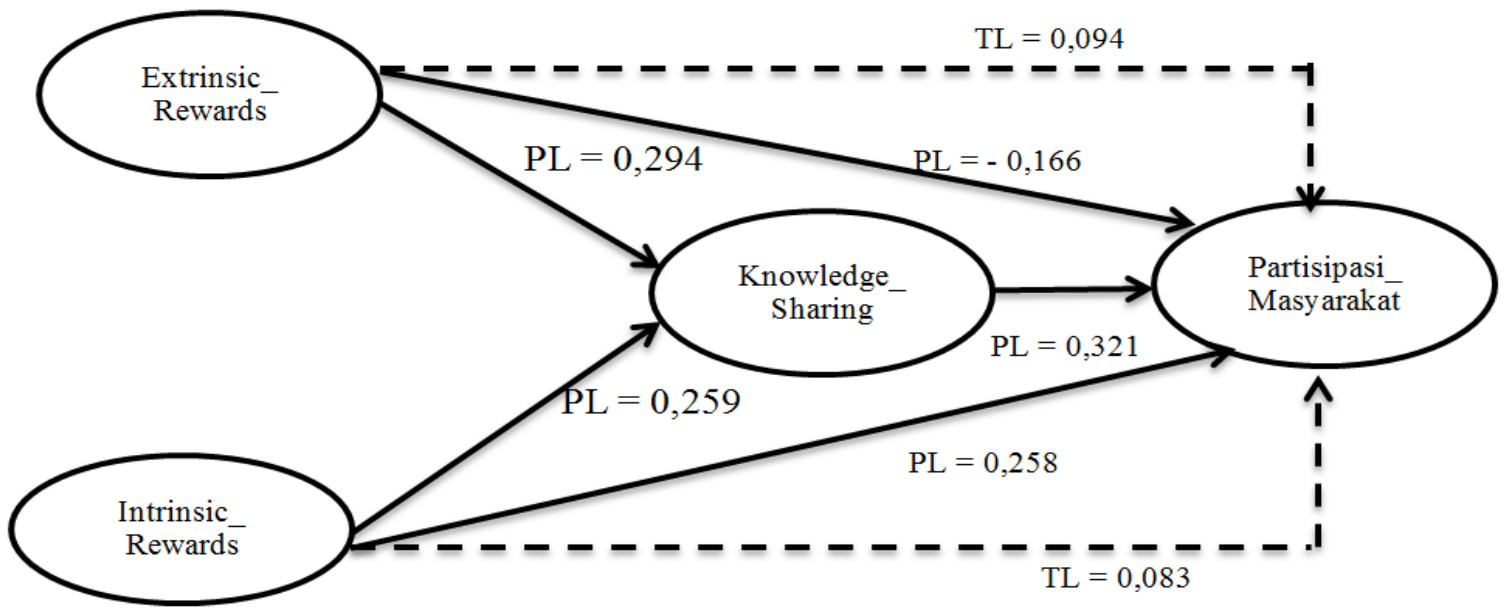

Gambar 3. Hasil Pengaruh Langsung, Tidak Langsung dan Total

Penjelasan Gambar :

PL $\rightarrow=$ Dimaknai sebagai Pengaruh Langsung digunakan garis penuh sebagai penanda

$\mathrm{TL} \rightarrow=$ Dimaknai sebagai Pengaruh Tidak Langsung digunakan garis putus sebagai penanda

\subsection{Pembahasan}

Penelitian ini menemukan hasil bahwa berdasarkan tabel 6 serta gambar 3, pengaruh langsung dari extrinsic rewards dan intrinsic rewards terhadap knowledge sharing didapatkan hasil adalah extrinsic rewards memiliki pengaruh langsung > (lebih besar) dari knowledge sharing yaitu dengan besarnya adalah 0,294 dibandingkan dengan pengaruh langsung dari variabel intrinsic rewards yaitu dengan besarnya adalah 0,259. Didapatkan pengaruh langsung extrinsic rewards, intrinsic rewards dan knowledge sharing terhadap partisipasi masyarakat dihasilkan kesimpulan sebagai berikut knowledge sharing mendapatkan makna dari hasil penelitian sebagai pengaruh paling besar terhadap variabel partisipasi masyarakat 
yaitu dengan besarnya adalah 0,321 dibandingkan dengan pengaruh langsung extrinsic rewards dengan besarnya adalah -0,166 atau hasil dari variabel intrinsic rewards dengan besarnya adalah 0,258 . Hasil dari penelitian ini sesuai dengan penelitian sebelumnya yang menyatakan bahwa intrinsic rewards memiliki pengaruh terhadap knowledge sharing, serta dibandingkan dengan variabel yang lainnya intrinsic rewards memberikan kontribusi yang lebih dominan [17]. Tetapi hasil dari penelitian ini tidak sesuai dengan penelitian sebelumnya yang menyatakan bahwa extrinsic rewards tidak memberikan pengaruh terhadap knowledge sharing apalagi dalam jangka panjang extrinsic rewards mungkin bukan motivator yang baik untuk mengembangkan knowledge sharing dalam komunitas virtual dalam jangka panjang [18]. Penelitian oleh Kalsom dkk (2010) didapatkan hasil bahwa ekstrinsik dan intrinsik rewards memberikan pengaruh terhadap knowledge sharing [19].

Kemudian pada Tabel 7 dan gambar 3, didapatkan hasil dari pengaruh tidak langsung variabel extrinsic rewards dengan variabel intrinsic rewards dibandingkan terhadap variabel partisipasi masyarakat dengan variabel intervening adalah knowledge sharing, didapatkan hasil yaitu extrinsic rewards pengaruh tidak langsung yang didapatkan adalah 0,094 daripada intrinsic rewards dengan besarnya 0,083. Hasil dari penelitian ini sesuai dengan penelitian sebelumnya yang menyatakan bahwa rewards berpengaruh terhadap partisipasi [20], hal ini sesuai dengan penelitian oleh Hsieh dan Kocielnik (2016) dengan hasil bahwa dengan diberikannya extrinsic rewards berpengaruh terhadap partisipasi [21].

Hasil yang didapatkan dari pengaruh langsung extrinsic rewards dibandingkan dengan partisipasi masyarakat dengan besar nya $0,294 \geq$ dari pada pengaruh tak langsung extrinsic rewards dibandingkan dengan partisipasi masyarakat dengan knowledge sharing sebagai variabel moderating dengan besarnya 0,094 serta hasil dari pengaruh langsung intrinsic rewards dibandingkan dengan partisipasi masyarakat dengan besarnya 0,259 dengan hasil sama yaitu $\geq$ dari pengaruh tak langsung terhadap variabel intrinsic rewards dibandingkan dengan partisipasi masyarakat melalui knowledge sharing dengan besarnya 0,083. Hasil dari penelitian ini bisa dimaknai bahwa knowledge sharing bukan variabel intervening di dalam penelitian ini.

Tabel 8 didapatkan hasil dari penelitian bahwa pengaruh total pada variabel extrinsic rewards dengan intrinsic rewards dibandingkan dengan knowledge sharing didapatkan makna hasil yaitu extrinsic rewards dengan pengaruh total dengan besarnya 0,294 adalah yang paling besar dibandingkan dari pengaruh total pada variabel intrinsic rewards dengan besarnya 0,259. Selanjutnya didapatkan dari hasil penelitian dan perhitungan bahwa 
pengaruh total pada variabel extrinsic rewards, intrinsic rewards dan knowledge sharing terhadap partisipasi masyarakat menunjukkan bahwa intrinsic rewards memiliki pengaruh total yang paling besar yaitu 0,341 terhadap partisipasi masyarakat dari pada pengaruh total extrinsic rewards $(-0,072)$ dan knowledge sharing $(0,321)$. Hasil dari penelitian ini sesuai dengan penelitian sebelumnya yang menyatakan bahwa knowledge sharing merupakan bagian integral dari manajemen pengetahuan, yang pada gilirannya memainkan peran penting dalam keterlibatan dan partisipasi seluruh anggota organisasi dalam pencapaian tujuan organisasi secara efisien [22].

Berdasarkan hasil dari penelitian ini, pihak perangkat desa yang ada di Kabupaten Kerinci perlu membangun budaya knowledge sharing di antara perangkat desa. Knowledge sharing yang didasari oleh adanya extrinsic rewards dan intrinsic rewards yang terbangun berdampak terhadap peningkatan partisipasi masyarakat. Extrinsic rewards dan intrinsic rewards yang berkembang pada perangkat desa merupakan suatu kebutuhan dengan tingkat yang berbeda, isi dan konteks yang disesuaikan dengan kinerja yang dihasilkan dari setiap perangkat desa. Temuan penelitian ini menunjukkan bahwa untuk memberikan dampak positif pada perangkat desa, fokus pada extrinsic rewards dan intrinsic rewards. Hal utama yang dapat diambil oleh para praktisi terutama pihak yang berkaitan dengan pembangunan desa dari penelitian ini adalah perangkat desa dapat dibina untuk membuat, menerapkan, dan berbagi knowledge sharing yang diinginkan oleh organisasi. Pihak pemerintah di level Kabupaten seperti Dinas yang membawahi pembangunan desa dapat membuat suatu desain platform untuk perangkat desa supaya terlibat dalam saling berbagi pengetahuan (knowledge sharing) dan pengalaman. Studi ini juga menunjukkan hal bahwa untuk menciptakan knowledge sharing dibutuhkan peningkatan reward baik itu extrinsic rewards dan intrinsic rewards.

\section{KESIMPULAN}

Hasil penelitian ini dapat disimpulkan bahwa pengujian hipotesis dari variabel extrinsic rewards dan intrinsic rewards berpengaruh positif serta signifikan terhadap knowledge sharing, knowledge sharing dan intrinsic rewards berpengaruh positif serta signifikan dengan variabel partisipasi masyarakat sedangkan extrinsic rewards berpengaruh tidak signifikan terhadap partisipasi masyarakat.

Hasil dari variabel yang paling mempengaruhi pada variabel partisipasi masyarakat adalah knowledge sharing dengan hasil pengaruh yang paling besar terhadap partisipasi 
masyarakat. Hasil dan nilai dari koefisien jalurnya sebesar 0,321 dengan makna hasil koefisien yang terbesar daripada hasil variabel extrinsic rewards yang didapatkan hasil yaitu 0,166 ataupun variabel intrinsic rewards $(0,258)$. Selanjutnya untuk melihat hasil dari pengaruh knowledge sharing didapatkan hasil bahwa variabel extrinsic rewards lebih besar terhadap variabel intrinsic rewards, sehingga hasil ini dimaknai lebih dominan dimana hasil yang didapatkan adalah sebesar 0,294 $\geq$ dari nilai yang didapatkan dari koefisien jalur intrinsic rewards dengan besarnya 0,259 .

Demikian juga didapatkan hasil bahwa knowledge sharing bukan merupakan variabel intervening karena pengaruh langsung extrinsic rewards terhadap partisipasi masyarakat $\geq$ dari pengaruh tidak langsung melalui knowledge sharing dan pengaruh langsung intrinsic rewards terhadap partisipasi masyarakat juga $\geq$ pengaruh tidak langsung terhadap partisipasi masyarakat dengan knowledge sharing sebagai variabel moderating-nya.

Hasil penelitian didapatkan hasil dari koefisien determinasi adalah dari knowledge sharing dipengaruhi oleh variabel extrinsic rewards dan intrinsic rewards sebesar $17 \%$. sedangkan koefisien determinasi persamaan partisipasi masyarakat sebesar 20,2\%.

\section{SARAN}

Saran didapatkan untuk penelitian ini adalah dari indikator-indikator pada loading standard yang relatif rendah. Dengan indikator yang rendah itulah dijadikan saran dan masukan bagi pihak yang berkepentingan seperti pimpinan dan instansi terkait, dengan hasil dari faktor loading terendah adalah pada re 5 (Extrinsic Rewards 5) yakni indikator Sistem Kinerja Berbasis Individu (Individual Based Performance System) dengan hasil adalah -0,003 sehingga bisa disarankan bahwa adanya standar pada perangkat desa mengenai pekerjaan yang dilaksanakan secara individu dengan sistem kinerja yang telah terintegrasi. Sehingga walaupun perangkat desa bekerja secara individu tetapi tetap sesuai dengan tugas pokok dan fungsinya. Faktor loading terendah berikutnya adalah pada ri 1 (Intrinsic Rewards 1) yakni indikator rasa bermakna (sense of meaning fullness) dengan hasil adalah - 0,117. Sehingga bisa disarankan pada indikator ini bahwa hendaknya perangkat desa bisa dihargai sehingga timbul rasa dari perangkat desa bahwa mereka merasa dihargai. 


\section{Ucapan Terima Kasih}

Penulis mengucapkan terima kasih kepada Direktorat Riset dan Pengabdian Masyarakat Direktorat Jenderal Riset dan Pengembangan Kementerian Riset, Teknologi, dan Pendidikan Tinggi atas dukungan finansial pada Penelitian Dosen Pemula (PDP) tahun 2020.

\section{DAFTAR PUSTAKA}

[1] H. V. Alam, Pengembangan Sumber Daya Aparatur Desa. Gorontalo: Ideas Publishing, 2017.

[2] J. Lee, "The Effects of Knowledge Sharing on Individual Creativity in Higher Education Institutions: Socio-Technical View," Adm. Sci., vol. 8, no. 2, p. 21, 2018.

[3] K. Abili, F. N. Thani, F. Mokhtarian, and M. M. Rashidi, "The role of effective factors on organizational knowledge sharing," Procedia - Soc. Behav. Sci., vol. 29, no. 2010, pp. 1701-1706, 2011.

[4] G. A. Putri and S. Raharso, "Pengaruh Knowledge Sharing Terhadap Kinerja Karyawan," J. Ris. Bisnis dan Investasi, vol. 1, no. 3, p. 81, 2016.

[5] M. Asrar-ul-Haq and S. Anwar, "A systematic review of knowledge management and knowledge sharing: Trends, issues, and challenges," Cogent Bus. Manag., vol. 3, no. 1, pp. 1-17, 2016.

[6] D. Paulin and K. Suneson, "Knowledge transfer, knowledge sharing and knowledge barriers-three blurry terms in KM," Proc. Eur. Conf. Knowl. Manag. ECKM, vol. 2, no. 1, pp. 752-760, 2011.

[7] A. Sarkheyli, R. A. Alias, N. Ithnin, and M. D. Esfahani, "Dimensions of Knowledge Sharing Quality: An Empirical Investigation," J. Res. Innov. Inf. Syst., vol. 0, no. May 2018, pp. 9-18, 2013.

[8] H. Özutku, "The Influence of Intrinsic and Extrinsic Rewards on Employee Results: An Empirical Analysis in Turkish Manufacturing Industry," Bus. Econ. Res. J., vol. 3, no. 3, pp. 29-48, 2012.

[9] C. Chekwa and D. Richardson, "Generational Gap: Intrinsic (Non-monetary) Versus Extrinsic (Monetary) Rewards in the Workforce," Chinese Bus. Rev., vol. 12, no. 06, pp. 414-424, 2013.

[10] O. Gov, "The complex relationship between intrinsic and extrinsic rewards," Econ. Bus. Rev., vol. 1, no. 15, pp. 102-125, 2015.

[11] C. A. Sénit, "Leaving no one behind? The influence of civil society participation on the Sustainable Development Goals," Environ. Plan. C Polit. Sp., vol. 38, no. 4, pp. 693-712, 2020.

[12] D. Campagna, G. Caperna, and V. Montalto, "Does Culture Make a Better Citizen? Exploring the Relationship Between Cultural and Civic Participation in Italy," Soc. Indic. Res., vol. 149, no. 2, pp. 657-686, 2020.

[13] A. Ernst, "How participation influences the perception of fairness, efficiency and effectiveness in environmental governance: An empirical analysis," J. Environ. Manage., vol. 238, no. March, pp. 368-381, 2019.

[14] A. M. H. Pardede et al., "Implementation of Data Mining to Classify the Consumer's Complaints of Electricity Usage Based on Consumer's Locations Using Clustering Method," J. Phys. Conf. Ser., vol. 1363, no. 1, 2019.

[15] S. Haryono, "Metode SEM untuk penelitian manajemen dengan AMOS LISREL PLS," Psychol. Appl. to Work An Introd. to Ind. Organ. Psychol. Tenth Ed. Paul, vol. 53, no. 
9, pp. 1689-1699, 2012.

[16] A. E. Sari, S. Salamah, and A. Albetris, "Dampak Dimensi Intellectual Capital Terhadap Knowledge Management Pendamping Desa di Kabupaten Kerinci," J-MAS (Jurnal Manaj. dan Sains), vol. 4, no. 2, p. 220, 2019.

[17] K. M. Bartol and A. Srivastava, "Encouraging Knowledge Sharing: The Role of Organizational Reward Systems," J. Leadersh. Organ. Stud., vol. 9, no. 1, pp. 64-76, 2002.

[18] C. C. Liu, T. P. Liang, B. Rajagopalan, and V. Sambamurthy, "The crowding effect of rewards on knowledgesharing behavior in virtual communities," in PACIS 2011 - 15th Pacific Asia Conference on Information Systems: Quality Research in Pacific, 2011.

[19] S. Kalsom, S. N. S. Ahmad, and S. O. S. S. Ikhsan, "Knowledge management and public sector accountants: Knowledge sharing process in the accountant general's department of Malaysia," IPN, vol. 1, no. 1, pp. 15-28, 2010.

[20] E. C. Sharp, L. G. Pelletier, and C. Lévesque, "The double-edged sword of rewards for participation in psychology experiments," Can. J. Behav. Sci., vol. 38, no. 3, pp. 269$277,2006$.

[21] G. Hsieh and R. Kocielnik, "You get who you pay for: The impact of incentives on participation bias," Proc. ACM Conf. Comput. Support. Coop. Work. CSCW, vol. 27, pp. 823-835, 2016.

[22] F. Ahmad and M. Karim, "Impacts of knowledge sharing: a review and directions for future research,” J. Work. Learn., vol. 31, no. 3, pp. 207-230, 2019. 